\title{
Labours
}

\section{old and new}

The parliamentary right of the British Labour Party 1970-79 and the roots of New Labour

Stephen Meredith 


\section{Labours old and new}

\section{MANCHESTER 1824}

Manchester University Press 


\section{Critical Labour Movement Studies}

Series editors

John Callaghan

Steven Fielding

Steve Ludlam

Already published in the series

Jenny Andersson

Between growth and security: Swedish social democracy from

a strong society to a third way

John Callaghan, Steven Fielding and Steve Ludlam (eds)

Interpreting the Labour Party: approaches to Labour politics

and history

Andrew Gamble, Steve Ludlam, Andrew Taylor and Stephen Wood (eds)

Labour, the state, social movements and the challenge of

neo-liberal globalisation

Dianne Hayter

Fightback! Labour's traditional right in the 1970s and 1980s

Jonas Hinnfors

Reinterpreting social democracy: a history of stability in the

British Labour Party and Swedish Social Democratic Party

Ben Jackson

Equality and the British Left: a study in progressive political

thought, 1900-64

Leighton James

The politics of identity and civil society in Britain and Germany:

miners in the Ruhr and South Wales 1890-1926

Declan McHugh

Labour in the city: the development of the Labour Party in

Manchester, 1918-31

Jeremy Nuttall

Psychological socialism: the Labour Party and qualities of mind

and character, 1931 to the present

Lucy Robinson

Gay men and the left in post-war Britain: how the personal

got political 


\section{Labours old and new}

The parliamentary right of the British Labour Party 1970-79 and the roots of New Labour

Stephen Meredith

Manchester University Press

Manchester and New York

distributed exclusively in the USA by Palgrave 
Copyright $\odot$ Stephen Meredith 2008

The right of Stephen Meredith to be identified as the author of this work has been asserted by him in accordance with the Copyright, Designs and Patents Act 1988.

Published by Manchester University Press Oxford Road, Manchester M13 9NR, UK

and Room 400, 175 Fifth Avenue, New York, NY 10010, USA

www.manchesteruniversitypress.co.uk

Distributed exclusively in the USA by

Palgrave, 175 Fifth Avenue, New York, NY 10010, USA

Distributed exclusively in Canada by UBC Press, University of British Columbia, 2029 West Mall, Vancouver, BC, Canada V6T 1Z2

British Library Cataloguing-in-Publication Data

A catalogue record for this book is available from the British Library

Library of Congress Cataloging-in-Publication Data applied for

ISBN 9780719073229 hardback

EISBN 9781847792242

First published 2008

$17161514131211100908 \quad 10987654321$ 